\title{
Development of an interactive tool based on Education ERPs Software to support the learning of Transversal Competences
}

\author{
Lina Montuori ${ }^{\mathrm{a}}$, Manuel Alcázar-Ortega ${ }^{\mathrm{b}}$, Carlos Vargas-Salgado $^{\mathrm{b}}$, Cristian \\ Chiñas-Palacios ${ }^{\mathrm{c}}$ \\ ${ }^{a}$ Universitat Politècnica de València, Department of Applied Thermodynamics. Valencia (Spain). \\ lmontuori@upvnet.upv.es, b Universitat Politècnica de València, Department of Electrical \\ Engineering. Valencia (Spain). malcazar@iie.upv.es, carvarsa@iie.upv.es, 'niversidad de \\ Guadalajara (Centro Universitario de Tonalà), Department of Studies for Water and Energy. Jalisco \\ (Mexico).daniel.chinas@academicos.udg.mx
}

\begin{abstract}
According to the current tendencies in University education strategies, students should develop not just the specific competences related to the particular degree they pursue, but also a series of transversal competences (TCs, also called key competences). Such TCs may be transferable between different contexts (personal, social, academic, etc.) while help students to solve problems from different perspectives and so, they would provide students with a holistic education and training. In this framework, the authors present in this paper a tool they have designed for the systematic analysis and evaluation of TCs so as to support students in the achievement of such competences. Moreover, the tool is able to help students to choose the courses that may help them to work out and complement the competences they may not be developed yet, as well as it suggests the most appropriate post-graduate courses for the students according to their background, particular interests and degree of development for the different TCs.

The tool has been designed under the scope of vertical ERP systems, which have demonstrated their ability to create collaborative and learning environments with multiple communication functionalities between professors and students. Thus, the tool has been thought as an interactive framework that includes different indexes to monitor the level of development of the diverse TCs, so that it may be accessible to both professors and students during their entire academic life. The tools have been tested within the program of Transversal Competences of the Polytechnic University of Valencia, specifically to the Degree of Energy Engineering.
\end{abstract}

Keywords: Vertical ERP, transversal competences, active learning, methodology, training, evaluation. 


\section{Introduction}

In the framework of the current education strategies at the University level, students should develop a sort of transversal competences (TCs), which in addition to the specific competences related to the particular degree they study, provide students with a holistic education and training (Villa \& Poblete, 2007). In the case of the Polytechnic University of Valencia, 13 TCs have been identified and, consequently, they are taught and worked out with students in the different undergraduate and graduate courses (Bonet Espinosa, Cabredo Fagrés, Calvet Sanz, de Andrés Martínez, \& Soto Pacheco, 2015).Previous research developed by the authors has evidenced the need for support tools to help students to take decisions related to the courses they should choose to better complement their training and development of TCs (Montuori, Alcázar-Ortega, Vargas-Salgado, \& Bastida-Molina, 2019). Therefore, such tools may guide students when choosing the most appropriate postgraduate courses so as to complement their career according to their academic and professional interests.

The tool here presented has been designed according to the Education ERPs (Enterprise Resource Planning) principles. ERP systems allow organizations to integrate the different operations and departments for a more efficient management of information and resources (Antonegi Martínez, Casadesús Fa, \& Zamanillo Elguezábal, 2005). In particular, an ERP system specifically designed for University education means an essential support for the management of the different areas involved in such activities as research, academics or economics (Cloud Factory, S.L., 2019) due to the different managerial functionalities that it includes (Educacion 3.0, 2018). One of the objectives of the tool here presented is to enhance the active and auto-regulated learning done by the students, which has been also experimented by some researchers at the High School level (Demkanin \& Kovác, 2018). In fact, the student is the actual responsible for its own learning process, that should not be limited to listen to the professor (Oltra Mestre, García Palao, Flor Peris, \& Boronat Navarro, 2012). This tool has been thought as a module that may be included in the platform Poliformat, which is already linked to the database where all the information related to the TCs evaluation for the graduate and undergraduate students is stored. On the other hand, Poliformat is a well-known environment which professors and students are used to. This fact would facilitate the implementation of the aforementioned tool as a complement of such platform.

This paper is organized as follows: Chapter 2 is devoted to present the methodology based on which the tool here presented has been developed. Following, a case of application is presented in Chapter 3, where the tool has been applied to the evaluation of undergraduate 
students enrolled in the Degree of Energy Engineering that is taught at the High School for Industrial Engineering at UPV. Finally, according to the obtained results, conclusions of this research are discussed and presented in Chapter 4.

\section{Methodology}

The proposed tool has been designed according to the methodology proposed by the authors in (Montuori, Alcázar-Ortega, Vargas-Salgado, \& Bastida-Molina, 2019) which, including some updates and improvements, may be summarized in the following steps:

1) Analysis of transversal competences and weighting. The first step will be the identification of transversal competences that are worked out in each of the studied courses during the considered undergraduate or graduate degree. Once identified, each competence will be weighted according to the number of credits devoted to its development during the degree, according to the following expression:

$$
W_{C T}^{i}=\frac{\sum_{n=1}^{N} \operatorname{ECTS}_{n}}{\sum_{m=1}^{M} E_{C T S_{m}}} \cdot 100(\%)
$$

Where $W_{C T}^{i}$ is the weight of transversal competence $i$ related to the total number of credits that are assigned to the degree; $E C T S_{n}$ is the number of credits for each course $n$ in which the transversal competence $i$ is worked out; and $E C T S_{m}$ is the number of credits for each $m$ course within the degree.

2) Analysis of optative courses. As one of the objectives of the tool is the support to students about the optative courses they may enroll in, the TCs that are worked out in each optative course related to the considered degree will be identified.

3) Definition of development thresholds and corrective actions. TCs are evaluated at UPV according to rubrics, which adopt a qualitative scale (A, B, C or D). In order to quantify the degree of development for each TC, the numerical scale included in Table 1 will be applied.

Table 1. Quantification scale to measure the level of development of TCs

\begin{tabular}{lrr}
\hline $\begin{array}{c}\text { Development degree } \\
\text { (Scale UPV) }\end{array}$ & $\begin{array}{c}\text { Numeric } \\
\text { grade (GR) }\end{array}$ & $\begin{array}{c}\text { Threshold to reach } \\
\text { the next grade }\end{array}$ \\
\hline A-Excellent & 10 & - \\
B-Acceptable & 8 & 9 \\
C-Developing & 6 & 7 \\
D-Not achieved & 4 & 5 \\
\hline
\end{tabular}


In the proposed methodology, it has been considered that levels $\mathrm{C}$ or $\mathrm{D}$ mean a nonappropriate development of the considered TC, so that corrective actions need to be applied. An example of such actions, based on the official rubrics developed by UPV for the TCs evaluation (Bonet Espinosa, Cabredo Fagrés, Calvet Sanz, de Andrés Martínez, \& Soto Pacheco, 2015) and which should be automatically proposed by the tool, is included in Table 2.

Table 2. Example of corrective actions to improve the performance of TC3

\begin{tabular}{|c|c|c|}
\hline$T C 3$ & Analys & is and problems reso \\
\hline Topic & Grade & Suggestion \\
\hline & D & $\begin{array}{l}\text { You should further work out the i } \\
\text { requested to solve }\end{array}$ \\
\hline Problem & $\mathrm{C}$ & to identify the most relevant informat \\
\hline defir & B & $\begin{array}{l}\text { You have reached a good competence on this topic, but you should define } \\
\text { problems more accurately }\end{array}$ \\
\hline & A & - You have reached an excellent competence on this topic \\
\hline & D & $\begin{array}{l}\text { You should identify and gather relevant information that is necessary to } \\
\text { solve problems }\end{array}$ \\
\hline & C & $\begin{array}{l}\text { - You should gather more relevant and consistent information to solve } \\
\text { problems }\end{array}$ \\
\hline & B & $\begin{array}{l}\text { You have reached a good competence on this topic, but you should further } \\
\text { justify the usefulness of gathered information }\end{array}$ \\
\hline & A & - You have reached an excellent competence on this topic \\
\hline & D & $\begin{array}{l}\text { You should use the methods you have learned in the course to solve the } \\
\text { problems }\end{array}$ \\
\hline & $\mathrm{C}$ & $\begin{array}{l}\text { - You should justify the calculations you do on each step (data, equations, } \\
\text { etc.) }\end{array}$ \\
\hline & B & $\begin{array}{l}\text { - You have reached a good competence on this topic, but you should assess } \\
\text { the adequacy of the used method (hypothesis, limitations, etc.) }\end{array}$ \\
\hline & A & - You have 1 \\
\hline & $\mathrm{D}$ & lize whether the obtained results a \\
\hline & $\mathrm{C}$ & - You should further justify the coherency of the obtained results \\
\hline consistency & B & $\begin{array}{l}\text { hed a good competence on this topic, but should be more } \\
\text { implications of the obtained solution }\end{array}$ \\
\hline & A & - You have reached an excellent competence on this topic \\
\hline
\end{tabular}

4) Definition of development timing. UPV considers three moments where TCs are evaluated. However, the tool may help students to monitor their level of development of the different TCs during their academic life, before the completion of the official level. In consequence, students may apply corrective actions or they could 
complement their training on TCs according to the level of development of each one of them.

5) Definition of performance factors. In order to quantify and standardize the monitoring of the level of development of transversal competences, different factors are calculated and evaluated. Those factors do not just allow students to evaluate if they have reached or not some competences, but also to automatically get a series of corrective actions to help them improving such competences development.

Three performance factors have been developed, which are calculated as follows:

a. Transversal Competences Performance Factor $\left(C_{t r}^{i}\right)$. It measures the level of development achieved by the student on each TC. It is defined as follows:

$$
C_{t r}^{i}=\frac{\sum_{n=1}^{N} G R_{n} \cdot \operatorname{ECTS}_{n}}{\sum_{n=1}^{N} E C T S_{n}}
$$

$G R_{n}$ is the degree of development achieved in the course $n$ for the TC $i$, according to the values indicated in Table 1; and ECTS $n$ is the number of credits of each $n$ course in which the TC $i$ is worked out.

b. Technical Interest Factor $\left(I^{k}{ }_{\text {tec }}\right)$. It measures the how interesting each $k$ optative course to be chosen by the student is. This factor is self-assigned by the student according to the Likert scale proposed in Table 3:

Table 3. Likert scale for the assessment of the Technical Interest Factor

\begin{tabular}{lccccc}
\hline Likert scale & $\begin{array}{c}\text { Totally } \\
\text { interested }\end{array}$ & $\begin{array}{c}\text { Very } \\
\text { interested }\end{array}$ & $\begin{array}{c}\text { Moderately } \\
\text { interested }\end{array}$ & $\begin{array}{c}\text { Little } \\
\text { interested }\end{array}$ & $\begin{array}{c}\text { Not } \\
\text { interested }\end{array}$ \\
\hline Numerical scale & 10 & 8 & 6 & 4 & 2 \\
\hline
\end{tabular}

c. Technological Affinity factor $\left(I^{k}{ }_{t e c}\right)$. It indicates the affinity of students on the more appropriate optative courses they may enroll in according to their profile, background and personal interest, as well as by the level of development of the related TCs that the student has achieved. This index is calculated as follows:

$$
A_{o p t}^{k}=I_{t e c}^{k} \cdot \frac{\sum_{i=1}^{13}\left(1-\frac{C_{t r}^{i}}{10}\right)}{N_{T C}^{k}}
$$

where the variables are those defined above and $N_{T C}^{k}$ is the number of TCs worked out in the optative course $k$. 
6) Analysis of results and feedback to students. Once the aforementioned factors have been calculated, the last step will be the interpretation of the obtained values and the feedback of recommendations to students, in line with the obtained results. An example application for such kind of analysis is presented in next section.

\section{Application and results}

The proposed method will be now applied to a fictitious "typical student" that is enrolled in the fourth course of the Degree in Energy Engineering at UPV. Fig. 1 shows the evaluation of TCs that will be used as basic case, whose assignation has been randomly done for a student that should decide the optative courses to be chosen for the $2^{\text {nd }}$ semester of the fourth academic year. Each course has been identified by a code, according to the standard classification of $\mathrm{UPV}^{1}$. Grades A, B, C and D for each TC have been painted in blue, green, orange and red, respectively.

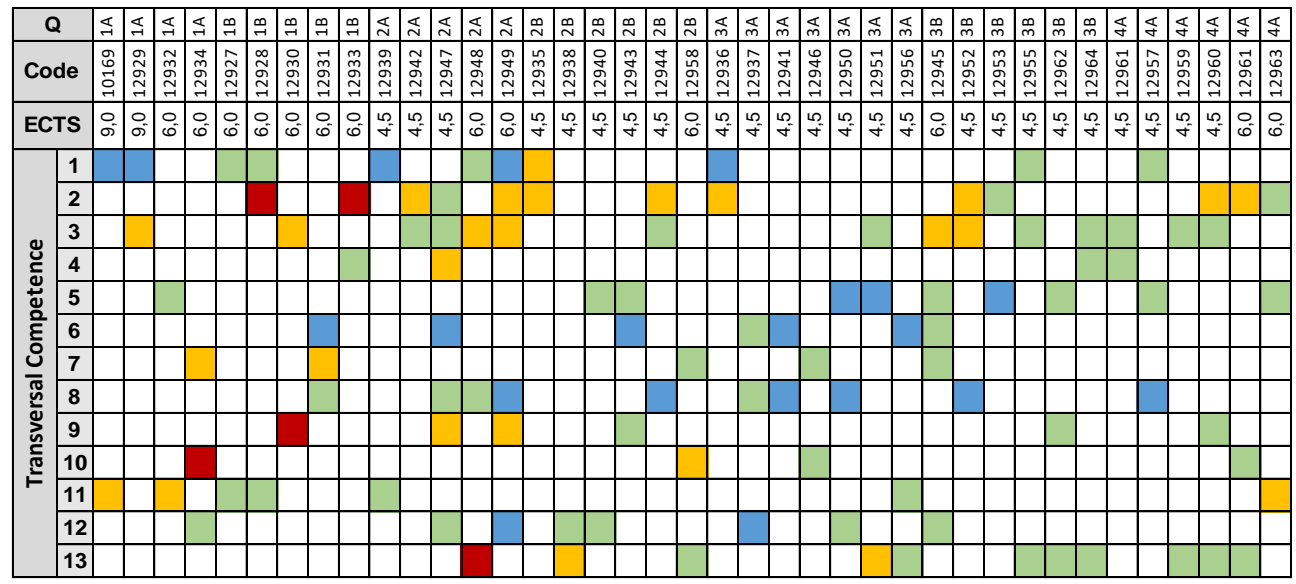

Fig. 1. Example de TCs' evaluation for an Energy Engineering student at UPV

Based on the grade obtained for each TC, the proposed tool would calculate the Competences Performance Factor according to (2), which would provide the student with the level of development of each TC up to the present time. The obtained results are shown in Table 4.

\footnotetext{
${ }^{1}$ http://www.upv.es/titulaciones/GIEN/menu_1015215c.html
} 
Table 4. Competences Performance Factor for the considered student, per TC

\begin{tabular}{|c|c|c|c|c|c|c|c|c|c|c|c|c|c|}
\hline & \multicolumn{13}{|c|}{ Transversal Competence } \\
\hline & 1 & 2 & 3 & 4 & 5 & 6 & 7 & 8 & 9 & 10 & 11 & 12 & 13 \\
\hline ECTS & 64,5 & 66,0 & 78,0 & 19,5 & 49,5 & 34,5 & 22,5 & 49,5 & 30,0 & 16,5 & 37,5 & 40,5 & 43,5 \\
\hline $\mathrm{C}_{\mathrm{tr}}^{\mathrm{i}}$ & 8,88 & 6,09 & 7,04 & 7,54 & 8,55 & 9,39 & 9,07 & 9,15 & 6,50 & 8,73 & 7,84 & 8,52 & 8,97 \\
\hline
\end{tabular}

According to Table 1, competences that have not been developed enough by the student are those with a grade lower than 7: TC2 and TC9.

Now, the student should indicate in the tool which of the optative courses are more interesting for him, which, according to the Likert scale shown in Table 3, will be translated into the Technical Interest Factor described in section 2. For this example, the assignation done in Table 5 has been considered. The ECTS for each optative course and the worked out TCs are also shown. Once students have indicated their preferences related to the optative courses, and according to the TCs worked out on each one, the tool calculates the Technological Affinity Factor according to (3).

Table 5. Competences Performance Factor for the considered student, per TC

\begin{tabular}{|c|c|c|c|c|c|c|c|c|c|c|c|c|c|c|}
\hline \multirow{2}{*}{ Code } & \multirow{2}{*}{ ECTS } & \multirow{2}{*}{$\mathbf{I}_{\text {tec }}^{\mathbf{k}}$} & \multicolumn{12}{|c|}{ Transversal Competence } \\
\hline & & & 1 & 2 & 3 & 4 & 5 & 6 & 7 & 8 & 9 & 10 & $11 \quad 12$ & 13 \\
\hline 12973 & 4,5 & 10 & & & & & & & & & & & & \\
\hline 13757 & 4,5 & 8 & & & & & & & & & & & & \\
\hline 12983 & 4,5 & 8 & & & & & & & & & & & & \\
\hline 12979 & 4,5 & 10 & & & & & & & & & & & & \\
\hline 12971 & 4,5 & 2 & & & & & & & & & & & & \\
\hline 12970 & 4,5 & 4 & & & & & & & & & & & & \\
\hline 12969 & 4,5 & 4 & & & & & & & & & & & & \\
\hline 12974 & 4,5 & 6 & & & & & & & & & & & & \\
\hline 12977 & 4,5 & 2 & & & & & & & & & & & & \\
\hline 12982 & 4,5 & 8 & & & & & & & & & & & & \\
\hline 13756 & 4,5 & 6 & & & & & & & & & & & & \\
\hline 12981 & 4,5 & 10 & & & & & & & & & & & & \\
\hline 12978 & 4,5 & 8 & & & & & & & & & & & & \\
\hline 12980 & 4,5 & 2 & & & & & & & & & & & & \\
\hline
\end{tabular}

Optative courses have been ranked according to the obtained value on the Technological Affinity Factor, as shown in Table 6. Considering the preference of the student and the TCs that should be further developed, courses 13757 and 12983 have been suggested the first. 
Table 6. Ranking of optative courses for recommendation to the student

\begin{tabular}{|c|c|c|c|c|c|c|c|c|c|c|c|c|c|c|c|}
\hline \multirow{2}{*}{$\begin{array}{l}\text { Ranking } \\
\text { position }\end{array}$} & \multirow{2}{*}{ Code } & \multirow{2}{*}{$\mathbf{A}^{\mathrm{k}}{ }_{\mathrm{opt}}$} & \multicolumn{13}{|c|}{ Worked out Transversal Competences } \\
\hline & & & 1 & 2 & 3 & 4 & 5 & 6 & 7 & 8 & 9 & 10 & 11 & 12 & 13 \\
\hline 1 & 13757 & 2,428 & & & & & & & & & & & & & \\
\hline 2 & 12983 & 2,315 & & & & & & & & & & & & & \\
\hline 3 & 13756 & 1,385 & & & & & & & & & & & & & \\
\hline 4 & 12973 & 1,075 & & & & & & & & & & & & & \\
\hline 5 & 12981 & 1,075 & & & & & & & & & & & & & \\
\hline 6 & 12982 & 0,860 & & & & & & & & & & & & & \\
\hline 7 & 12978 & 0,860 & & & & & & & & & & & & & \\
\hline 8 & 12970 & 0,722 & & & & & & & & & & & & & \\
\hline 9 & 12974 & 0,605 & & & & & & & & & & & & & \\
\hline 10 & 12969 & 0,505 & & & & & & & & & & & & & \\
\hline 11 & 12971 & 0,287 & & & & & & & & & & & & & \\
\hline 12 & 12977 & 0,215 & & & & & & & & & & & & & \\
\hline 13 & 12980 & 0,215 & & & & & & & & & & & & & \\
\hline 14 & 12979 & - & & & & & & & & & & & & & \\
\hline
\end{tabular}

The suitability of the proposed factor arises here when the student gets the most appropriate courses to improve the TCs that have been less developed, while the proposed courses also satisfy the condition of technical interest. It is interesting to point out as courses 12981 and 12979 appear in positions 5 and 14 of the ranking even if the student said he was totally interested on them. However, the most interesting TCs for the student are not worked out on such courses, so that other optative courses are marked as a better option for the student.

\section{Conclusions}

A novel ERP based tool to support students to better develop their transversal competences is presented in this paper. This tool would assist students in the election of optative courses to further develop the transversal competences they acquire when pursuing their degree, as well as to monitor the level of development of such competences during their whole career. This tool may also help students to choose the most appropriate postgraduate degree according to their academic and professional interests. The tool may allow students to introduce their preferences on which competences they would like to further develop in order to complement their $\mathrm{CV}$. Thus, related to that, they would receive automatic suggestions on how to get this goal. In the case of UPV, this tool could be integrated in the platform Poliformat since it is an environment at which professors and students are used to. 


\section{References}

Antonegi Martínez, J., Casadesús Fa, M., \& Zamanillo Elguezábal, I. (2005). Evolución histórica de los sistemas ERP: de la gestión de materiales a la empresa digital. Revista de Dirección y Administración de Empresas(12), 61-72.

Bonet Espinosa, P., Cabredo Fagrés, M., Calvet Sanz, S., de Andrés Martínez, D., \& Soto Pacheco, P. (2015). Proyecto Competencias Transversales UPV. Valencia: Universitat Politècnica de València.

Cloud Factory, S.L. (2019). S-ERP Online: Software de gestión para centros educativos. Recuperado el 06 de 05 de 2019, de https://conpas.net/sector_educacion_html

Demkanin, P., \& Kovác, M. (2018). Physics experiments planned by the students themselves - Higher Secondary Education. INNODOCT 2018, 14-16 November (págs. 23-33). Valencia (Spain): UPV.

Educacion 3.0. (2018). 35 plataformas para la gestión de centros educativos. Recuperado el 06 de 05 de 2019, de https://educaciontrespuntocero.com

Montuori, L., Alcázar-Ortega, M., Vargas-Salgado, C., \& Bastida-Molina, P. (2019). Metodología para fomentar el aprendizaje activo de competencias específicas y transversales a través del soporte de softwares ERPs educativos. V Congreso de Innovación Educativa y Docencia en Red $I N-R E D$ (pp. 1-15). Valencia: Universitat Politécnica de Valéncia.

Oltra Mestre, M., García Palao, C., Flor Peris, M., \& Boronat Navarro, M. (2012). Aprendizaje activo y desempeño del estudiante: diseño de un curso de dirección de la producción. Working papers on operations management (ISSN 1989-9068), 3(2), 84-102.

Villa, A., \& Poblete, M. (2007). Aprendizaje basado en competencias: una propuesta para la evaluación de las competencias genéricas. Bilbao: Ed. Mensajero - Universidad de Deusto. 